\title{
Stability evaluation of occlusal changes obtained with Fränkel's Function Regulator-2
}

Tânia Gnecchi Tanaka1, Fernanda Angelieri², Lylian Kazumi Kanashiro³ ${ }^{3}$ Silvana Bommarito ${ }^{4}$

Objective: To analyze the stability of occlusal changes promoted by the Frankel's Functional Regulator 2 (FR-2), in a mean period of 7.16 years post treatment. Methods: Fifty-four pairs of models were evaluated, from 18 patients treated with FR-2. All patients had Class II, division 1 malocclusion, with initial mean age of 10.77 years and were treated with FR-2 for 18 months. The models were evaluated at the beginning of treatment $\left(\mathrm{T}_{1}\right)$, at the end $\left(\mathrm{T}_{2}\right)$ and after 7.16 years post treatment $\left(\mathrm{T}_{3}\right)$. For occlusal evaluation, the treatment priority index (TPI) was applied on the three analyzed phases. The alterations that occurred between phases were verified with one another through paired Student's $t$ test, with critical value of 0.05 . Results: A statistically significant reduction of TPI was verified, from the initial to the final phase of the treatment, reflecting the efficiency of treatment performed with FR-2, specially due to improvement in molar relation, overjet and overbite. Apart from this, the Class II correction remained stable over time. Conclusions: In this way, it is concluded that the FR-2 appliance showed to be efficient for the dental correction of Class II malocclusion, with stable occlusal results after 7.16 years post treatment.

Keywords: Angle Class II malocclusion. Orthodontic appliances. Dental models.

Objetivo: analisar a estabilidade das alterações oclusais promovidas pelo aparelho Regulador de Função Fränkel-2 (RF-2), num período médio de 7,16 anos pós-tratamento. Métodos: foram avaliados 54 pares de modelos, provenientes de 18 pacientes tratados por meio do aparelho RF-2. Todos os pacientes possuíam má oclusão de Classe II, divisão 1, com idade inicial média de 10,77 anos e foram tratados com o RF-2 por 18 meses. Os modelos foram avaliados no início do tratamento $\left(\mathrm{T}_{1}\right)$, no final do tratamento $\left(\mathrm{T}_{2}\right)$ e decorridos 7,16 anos pós-tratamento ativo $\left(\mathrm{T}_{3}\right.$ ). Para a avaliação oclusal, aplicou-se o Índice de Prioridade de Tratamento (IPT) nas três fases analisadas. As alterações ocorridas entre as fases foram verificadas entre si por meio do teste $t$ de Student pareado, com o valor crítico adotado de 0,05. Resultados: verificou-se uma diminuição estatisticamente significativa do IPT, da fase inicial à final de tratamento, refletindo a eficácia do tratamento realizado por meio do RF-2, principalmente devido à melhora da relação molar, do trespasse horizontal e vertical. Além disso, a correção da má oclusão de Classe II obtida permaneceu estável no decorrer do tempo. Conclusão: concluiu-se que o aparelho RF-2 demonstrou ser eficaz na correção dentária da má oclusão de Classe II, com resultados oclusais estáveis decorridos 7,16 anos pós-tratamento.

Palavras-chave: Má oclusão de Angle Classe II. Aparelhos ortopédicos. Modelos dentários.

${ }^{1}$ Assistant Professor, Graduate Program in Orthodontics, APCD-Santo André Regional.

${ }^{2}$ Professor, Graduate Program in Dentistry, Division of Orthodontics, Methodist University of São Paulo.

${ }^{3}$ Professor, Graduate Program in Dentistry, Division of Orthodontics, Methodist University of São Paulo.

${ }^{4}$ Full Professor, Graduate Program in Dentistry, Division of Orthodontics, Methodist University of São Paulo.

» The author reports no commercial, proprietary or financial interest in the products or companies described in this article.
How to cite this article: Tanaka TG, Angelieri F, Kanashiro LK, Bommarito S. Stability evaluation of occlusal changes obtained with Fränkel's Function Regulator-2. Dental Press J Orthod. 2012 Nov-Dec;17(6):103-10.

Submitted: March 24, 2009 - Revised and accepted: August 16, 2009

Contact address: Tânia Gnecchi Tanaka

Rua Stella Bruna Cecchi Nardelli, 227, Sala 41 - Centro - Ribeirão Pires/SP - Brazil CEP: 09400-150 - E-mail: tania.gnecchi@terra.com.br 


\section{INTRODUCTION}

Class II, division 1 malocclusion, involves maxillary dental and/or skeletal alterations. According to McNamara $\mathrm{Jr},{ }^{21}$ this malocclusion has a higher prevalence of mandibular retrusion in relation to maxillary protrusion. In such cases, the therapy of choice should include the use of facial orthopedic appliances resulting in a mandibular advancement, as long as the patient presents potential for craniofacial growth. ${ }^{5,20}$

One of the great advantages of functional appliances is related to a less extreme treatment approach than extractions, and when used during the pubertal growth peak they can correct dental and skeletal discrepancies in the sagittal, vertical and transversal directions. ${ }^{5}$

When analyzing the various types of appliances described in the literature for orthopedic correction, the Fränkel functional regulator appliance (FR-2) is an alternative, as recommended by Rolf Fränkel. ${ }^{8}$ According to Fränkel ${ }^{9} \mathrm{FR}-2$ is indicated in the early stage of mixed dentition, between 6.5 and 8 years old for the Class II, division 1 malocclusion, with mandibular retrognathia, presenting strong horizontal and vertical over bite, however, in the presence of severe upper incisor protrusion, a pretreatment is advisable for reducing it.

The main effects caused by this appliance are: 1) An average increase in the overall mandibular length from 3.3 to $4.4 \mathrm{~mm} ; ;^{4,18,20,23} 2$ ) An increase of lower anterior facial height; ${ }^{1,4,17,18,20} 3$ ) Uprighting of maxillary incisors and buccal movement of lower incisors; ; $;^{1,410,20,25}$ 4) Decrease of maxillary anterior growth; ;,10,20,25 5) Distalization of upper molars; ${ }^{4,20}$ 6) Extrusion of lower molars ${ }^{4,17,20}$ and 7) increase of transversal arches width because this appliance works on the facial and masticatory musculature by applying shields to reach the bottom of the vestibule. This particular position of the shields promotes oral muscles relaxation causing traction of the periosteum, leading to bone growth stimulation. This allows the alteration of dentoalveolar development and contributes to the correction of dental trauma atresia. ${ }^{10,14,19}$ This way, the action of vestibular shields in perioral and buccinator muscles creates an appropriate functional space, allowing the mandible to advance in anterior direction. ${ }^{9}$
However, the increase in mandibular length obtained during treatment for correction of Class II malocclusion, when compared to a control group, has been questioned in literature regarding their effective gain over time. According DeVincenzo, ${ }^{6}$ Herbst appliance caused a significant increase in mandibular length during treatment and also 2 years after treatment, then decreasing after 3 years, in relation to the control group. However, after four years of treatment, the mandibular length in the treated group did not differ statistically significant from the control group, being equated.

However, there are few studies evaluating the stability of the effects promoted by the FR-2. Differently from the results of DeVincenzo, ${ }^{6}$ Perillo, Johnston and Ferro, ${ }^{23}$ observed an improvement of the maxillomandibular relation with an increase of mandibular length in the group treated with FR-2 in relation to control group. The authors concluded that this increase in mandibular length remained five years after treatment without any relapse.

Now, regarding the stability of transverse changes promoted by FR-2, Hime and Owen ${ }^{14}$ observed that in the mean period of four years after treatment with this appliance, followed by fixed appliances, there was increased stability of intercanine distances, inter-first and second premolars and intermolars in the lower arch. The lower dental arch length decreased with treatment and continued to decrease during posttreatment.

It is clearly important for the orthodontist to verify the stability of mandibular length increase promoted by FR-2 over time. However, clinically, the changes promoted by the stability of orthodontic/orthopedic treatment will be observed by the patients by checking the intra and interarch relation. As a result of this and the lack of longitudinal studies examining the stability of the occlusal outcomes promoted by the FR-2, the aim of this study was to evaluate the changes in dental arches resulting from the use of FR-2 appliance and the stability of its effects in long-term by analyzing dental casts applying the TPI occlusal index.

\section{MATERIAL AND METHODS}

\section{Material}

The sample included 54 pairs of study models from 18 patients, Caucasians, with Class II maloc- 
clusion, division 1, 7 patients had an end-on Class II molar relation and 11 complete Class II molar relation, 10 were males and 8 females. It were obtained from each patient the models in three different phases of treatment with FR-2: Initial ( $\left.\mathrm{T}_{1}\right)$, final (after 18 months of active use) $\left(\mathrm{T}_{2}\right)$; after treatment (after mean of 7.16 years posttreatment) $\left(\mathrm{T}_{3}\right)$ as shown in Table 1. These patients were part of a sample previously treated in the Methodist University of Sao Paulo by a single operator, student of the Master's Program in Dentistry, Division of Orthodontics. ${ }^{7}$

To select the sample of individuals who would perform orthopedic treatment with FR-2, the following criteria was used: ${ }^{7}$

»Class II, division 1 malocclusion associated with mandibular retrusion.

» Presence of Class II molar relationship of at least end-on.

» No history of previous orthodontic treatment.

»Absence of moderate to severe crowding.

»Absence of posterior crossbite.

Patients used the FR-2 for 18 months until the Class II correction. The appliance itself was used as over night retainer for 6 months on average. Patients were reevaluated after a mean of 6.66 years, after the retention period. To compose the sample of this study patients who had not undergone fixed orthodontic treatment in the post-retention stage with FR-2 were selected.

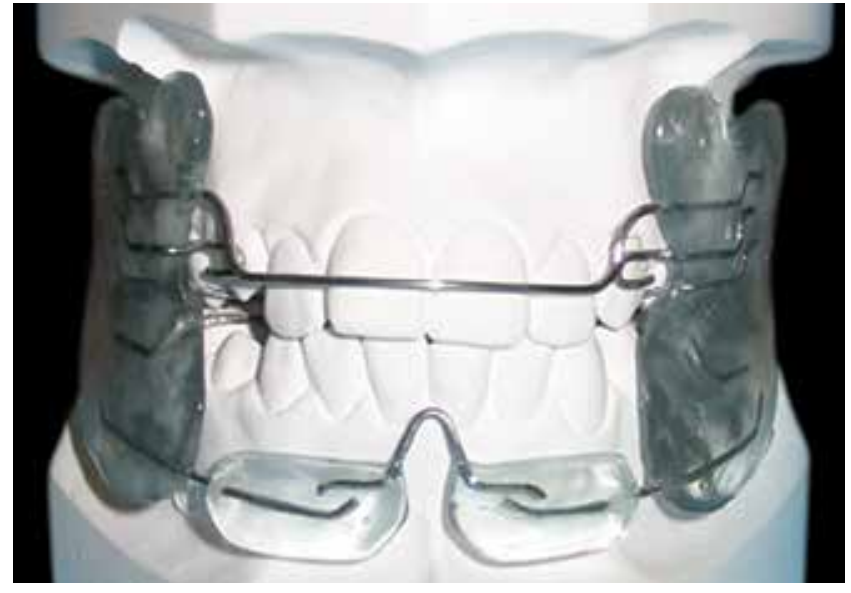

Figure 1 - FR-2 appliance: Frontal and lateral views.

\section{METHODS \\ Orthopedic treatment}

The treatment was performed with the FR-2 appliance as prescribed by Fränkel in $1966^{\circ}$. The mandibular advancement was achieved gradually, initially not more than $4 \mathrm{~mm}$, with the aim of increasing mandibular growth in the anteroposterior direction to obtain a Class I molar relationship. Also, a transverse increase of the arches was sought through the muscular balance provided by the appliance, due to the action of the vestibular shields (Figs $1 \mathrm{~A}$ and B).

The use of the appliance was indicated for 22 hours a day, being removed only for meals and cleaning, totaling a period of active treatment of 18 months in average. At the end of the period of active use, the patients used the FR-2 over night, for 6 months, with the purpose of retention.

\section{Obtaining the study models}

Impressions were taken of the upper and lower dental arches, reproducing all the teeth, alveolar process and buccal groove of the oral cavity for each patient. The casts were made with alginate, and the impressions were immediately poured with plaster, manipulated 30 seconds in a vacuum spatula (Polidental), followed by the use of a vibrating table (Knebel). The record of the patient's occlusion was performed by means of two folded wax sheets subsequently used for proper model clipping. A total of 54 pairs of models were analyzed, obtained from 18 patients at $\mathrm{T}_{1}$ (before treatment); $\mathrm{T}_{2}$ (after removal of FR-2), and $\mathrm{T}_{3}$ (7.16 years on average, after treatment with FR-2).

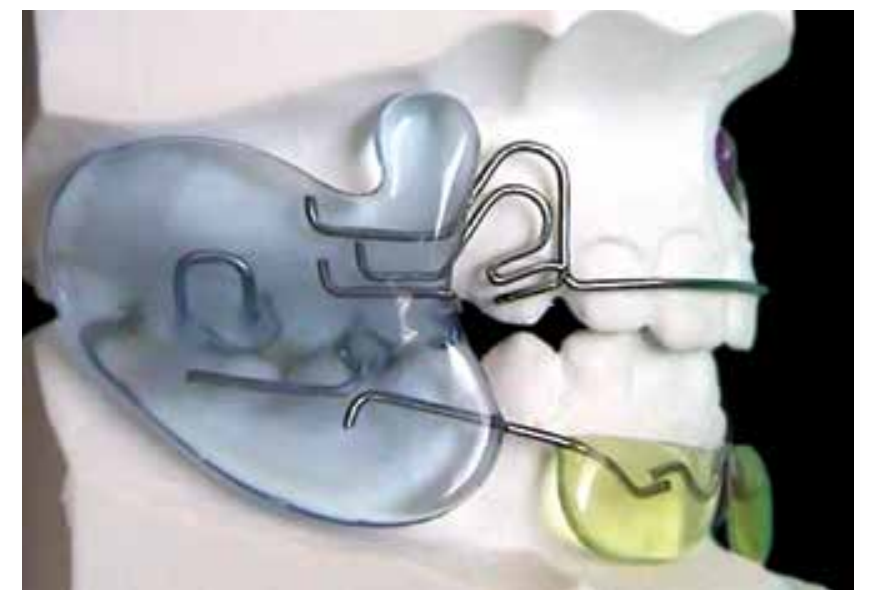




\section{Occlusal measurements: TPI}

For the occlusal evaluation on models at the initial, final and after treatment stages, the TPI index proposed by Grainger ${ }^{12}$ was used.

To perform the TPI index calculation, the subscores defined by the overbite and overjet dimensions, the number of displaced teeth to buccal or lingual rotations and posterior crossbites must be added up, following the column predetermined by molar anterior posterior relationship illustrated in Table 1 . With the exception of the rotation and buccal or lingual displacement all other TPI components are expressed along a continuous scale with positive and negative values. Inverted overjet cases, such as Class III malocclusion and / or anterior open bite are expressed with negative horizontal and vertical scores, respectively. A constant corresponding to molar relation is added to TPI score. The TPI score ranges from 0 to 10, and the higher the score, the more severe is the malocclusion (Table 1).

The TPI index components are defined based on the following criteria:

»First molar relationship: Defined by a constant that reflects the severity of malocclusion. Based on the sagittal relation between the upper and lower first molars.

» Overjet: Distance from the labial incisal edge of most prominent maxillary central incisor to the labial surface over the incisal edge of the opposite lower central incisor, parallel to the occlusal plane.

» Overbite: Amount of vertical overlap of the maxillary central incisor on the lower central incisor, taken in relation to the amount of crown height of lower central incisor.

» Tooth displacement: Is the sum of the number of teeth noticeably rotated or displaced from ideal alignment, above $45^{\circ}$ for the posterior teeth and with a displacement greater than $2 \mathrm{~mm}$ for anterior teeth.

»Crossbite: Buccal or lingual displacement of the posterior teeth. A crossbite is measured according to the number of teeth distant from the ideal relation cusp-fossa.

The TPI index was calculated for each pair of models in stages $\mathrm{T}_{1}, \mathrm{~T}_{2}$ and $\mathrm{T}_{3}$, with three tables for each patient.

It is noteworthy that all the casts were analyzed by a single examiner, previously calibrated, the results being transcribed in tables for statistical analysis.

\section{Error control}

Ten pairs of models in the three stages of development were randomly selected, on a minimum of 15 days after the first measurement. Thus, two sets of measures were obtained for the same patient in the same stage, carried out under the same conditions, but at different times.

\section{Statistical analysis}

For the assessment of methodological error, tests were applied to analyze the Dahlberg random error, and the Student's $t$ test for paired data for verification of systematic error.

Dahlberg's formula: $\mathrm{Se}=\sqrt{ } \Sigma \mathrm{d}^{2} / 2 n$ ("d" indicates the difference between the measurements of the same variable, and " $n$ " indicates the number of compared cephalograms pairs).

For statistical analysis of obtained data, the analysis of variance (ANOVA) was used for repeated measures in the different observation periods $\left(\mathrm{T}_{1}, \mathrm{~T}_{2}, \mathrm{~T}_{3}\right)$. When statistically significant difference occurred in the ANOVA test Bonferroni's multiple comparisons test was applied. The critical value was 0.05 .

\section{RESULTS}

The data relating to method error are shown on Table 2.

There was no systematic error - paired ttest $(\mathrm{p}>0.05)$ or even casual (all Dahlberg's errors were lower than 1$){ }^{15}$

\section{Treatment Priority Index (TPI)}

Tables 3 and 4 show changes in TPI during and after treatment with FR-2.

Occlusal Changes promoted by FR-2 and its stability during the 7.16 years post-treatment are available in tables 3 and 4. It was found that the treatment with FR-2 was very effective, correcting in a statistically significant way the initial Class II malocclusion, with much lower values of TPI by the end of treatment compared to the beginning $\left(\mathrm{T}_{2}-\mathrm{T}_{1}\right)$. In addition, the correction of Class II malocclusion with FR-2 showed an occlusal stability after 7.16 years from the end of active treatment $\left(\mathrm{T}_{2}-\mathrm{T}_{3}\right)$.

\section{DISCUSSION}

The occlusal indexes have been used in orthodontics, both in public health and scientific research, with a special purpose of evaluating the severity of 
Table 1 - Treatment Priority Index.

\begin{tabular}{|c|c|c|c|c|c|c|c|c|c|c|c|c|c|c|}
\hline & & & & & Distoc & lusion & & & & ) Mesi & cclusio & & & \\
\hline $\begin{array}{l}\text { First molar } \\
\text { relation } \\
\text { (choose th }\end{array}$ & propriate cc & umn) & & & $\begin{array}{c}1 \text { side } \\
1 \text { 1² Cl. II } \\
\text { and } 1 \\
\text { side } \\
\text { full } \\
\text { Cl. II }\end{array}$ & $\begin{array}{c}2 \\
\text { sides } \\
1 / 2 \\
\text { Cl. II } \\
\text { or } 1 \\
\text { side } \\
\text { full } \\
\text { Cl. II }\end{array}$ & $\begin{array}{c}1 \text { side } \\
1 / 2 \\
\text { Cl. II }\end{array}$ & $\begin{array}{l}N \\
E \\
U \\
T \\
R \\
A \\
L\end{array}$ & $\begin{array}{c}1 \text { side } \\
1 / 2 \mathrm{Cl} \text {. III }\end{array}$ & $\begin{array}{c}2 \\
\text { sides } \\
1 / 2 \\
\mathrm{Cl} . \mathrm{III} \\
\text { or } 1 \\
\text { side } \\
\text { full } \\
\mathrm{Cl} . \mathrm{III}\end{array}$ & $\begin{array}{l}1 \text { side } \\
1 / 2 \\
\text { Cl. III } \\
\text { and } 1 \\
\text { side } \\
\text { full } \\
\text { Cl. III }\end{array}$ & $\begin{array}{c}2 \\
\text { sides } \\
\text { full } \\
\text { Class } \\
\text { III }\end{array}$ & $\begin{array}{c}\text { W } \\
E \\
\text { I } \\
G \\
H \\
T\end{array}$ & $\begin{array}{l}\text { Type of } \\
\text { syndrome }\end{array}$ \\
\hline Incisor hor & tal & $\mathrm{mm}$ & & & & & & & & & & & & \\
\hline relation & & $>9$ & & & 3.4 & 5.4 & 9.3 & $10+$ & 9.3 & 5.4 & 3.4 & 2.0 & & \\
\hline & & 9 & & & 2.5 & 4.0 & 6.9 & $10+$ & 6.9 & 4.0 & 2.5 & 1.4 & & \\
\hline (1) Upper & & 8 & & & 1.8 & 2.8 & 4.8 & 8.0 & 4.8 & 2.8 & 1.8 & 1.0 & & Retrognathism \\
\hline overjet & & 7 & & & 1.1 & 1.8 & 3.0 & 5.1 & 3.0 & 1.8 & 1.1 & 0.6 & & \\
\hline & & 6 & & & 0.6 & 1.0 & 1.7 & 2.9 & 1.7 & 1.0 & 0.6 & 0.4 & & \\
\hline & $\mathrm{RMAL}$ & 5 & & & 0.3 & 0.4 & 0.8 & 1.3 & 0.8 & 0.4 & 0.3 & 0.2 & & \\
\hline & ting 0 & 1 & & & 0.3 & 0.4 & 0.8 & 1.3 & 0.8 & 0.4 & 0.3 & 0.2 & & \\
\hline & & 0 & & & 0.6 & 1.0 & 10.7 & 2.9 & 1.7 & 1.0 & 0.6 & 0.4 & & \\
\hline & & 1 & & & 1.1 & 1.8 & 3.0 & 5.0 & 3.0 & 1.8 & 1.1 & 0.6 & & Prognathism \\
\hline (2) Lower & & 2 & & & 1.8 & 2.8 & 4.8 & 8.0 & 4.8 & 2.8 & 1.8 & 1.0 & & rrogidtnism \\
\hline overjet & & 3 & & & 2.5 & 4.0 & 6.9 & $10+$ & 6.9 & 4.0 & 2.5 & 1.4 & & \\
\hline & & $>3$ & & & 3.4 & 5.4 & 9.3 & $10+$ & 9.3 & 5.4 & 3.4 & 2.0 & & \\
\hline Incisor ver & & & & & & & & & & & & & & \\
\hline relation & & $>3 / 3$ & & & 3.8 & 4.8 & 6.2 & 8.0 & 6.2 & 4.8 & 3.8 & 2.9 & & \\
\hline & $2 / 3$ & to $3 / 3$ & & & 2.0 & 2.4 & 3.2 & 4.1 & 3.2 & 2.4 & 2.0 & 1.5 & & Overhito \\
\hline $\begin{array}{l}\text { (3) overbit } \\
\text { relation to } \\
\text { crown thirc }\end{array}$ & $1 / 3$ & to $2 / 3$ & & & 0.7 & 0.9 & 1.1 & 1.5 & 1.1 & 0.9 & 0.7 & 0.5 & & uverolte \\
\hline 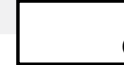 & $\begin{array}{l}\text { MAL } \\
\text { ting } 0\end{array}$ & & & & & & & & & & & & & \\
\hline & & $<2$ & & & 2.0 & 2.4 & 3.2 & 4.1 & 3.2 & 2.4 & 2.0 & 1.5 & & \\
\hline (4) open b & & 2 to 4 & & & 3.8 & 4.87 & 6.2 & 8.0 & 6.2 & 4.8 & 3.8 & 2.9 & & Open bite \\
\hline in $\mathrm{mm}$ & & $>4$ & & & 6.3 & 7.9 & $10+$ & $10+$ & $10+$ & 7.9 & 6.3 & 4.9 & & \\
\hline $\begin{array}{l}\text { (10) Teeth } \\
\text { displacem }\end{array}$ & & & & & & & & & & & & & & $\begin{array}{l}\text { Distocclusion and/or } \\
\text { posterior buccal crossbite }\end{array}$ \\
\hline - Sum of te & rotated & 2 & & & 0.1 & 0.2 & 0.3 & 0.4 & 0.3 & 0.2 & 0.1 & 0.1 & & Mauher \\
\hline $45^{\circ}$ or $2 \mathrm{~m}$ & & 3 & & & 0.3 & 0.4 & 0.7 & 1.1 & 0.7 & 0.4 & 0.3 & 0.2 & & \\
\hline displaced & & 4 & & & 0.5 & 0.9 & 1.2 & 1.9 & 1.2 & 0.9 & 0.5 & 0.3 & & \\
\hline - Sum of te & & 5 & & & 0.8 & 1.2 & 1.9 & 3.0 & 1.9 & 1.2 & 0.8 & 0.5 & & YES: - maxilla \\
\hline rotated $>4$ & & 6 & & & 1.1 & 1.8 & 2.8 & 4.3 & 2.8 & 1.8 & 1.1 & 0.7 & & - Brodie syndrome \\
\hline or displace & $\mathrm{mm} \times 2$ & 7 & & & 1.5 & 2.4 & 3.9 & 5.9 & 3.9 & 2.4 & 1.5 & 1.0 & & - brode synarome \\
\hline - Total $(0,1$ & hout & 8 & & & 1.9 & 3.1 & 4.9 & 7.7 & 4.9 & 3.1 & 1.9 & 1.3 & & TVu. - Mlaxila \\
\hline counting) & & 9 & & & 2.5 & 4.1 & 6.2 & 9.7 & 6.2 & 4.1 & 2.5 & 1.7 & & - collapse \\
\hline & & $>9$ & & & 3.0 & 4.9 & 7.7 & $10+$ & 7.7 & 4.9 & 3.0 & 2.0 & & \\
\hline Constants & & & & & 3.95 & 2.72 & 1.50 & 0.27 & 1.50 & 2.72 & 3.95 & 5.17 & & \\
\hline & $\begin{array}{l}\text { Buccal } \\
\text { upper }\end{array}$ & $N^{0}$ & 0 & 1 & 2 & 3 & 4 & 5 & 6 & 7 & 8 & more & & \\
\hline 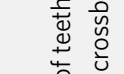 & $\begin{array}{l}\text { posterior } \\
\text { teeth }\end{array}$ & weight & 0 & 0.1 & 0.6 & 1.3 & 2.2 & 3.5 & 5.0 & 6.9 & 9.0 & 10 & & \\
\hline 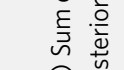 & $\begin{array}{l}\text { Lingual } \\
\text { upper }\end{array}$ & $N^{\circ}$ & 0 & 1 & 2 & 3 & 4 & 5 & 6 & & more & & & \\
\hline$\infty \simeq$ & $\begin{array}{l}\text { posterior } \\
\text { teeth }\end{array}$ & weight & 0 & 0.3 & 1.0 & 2.3 & 4.2 & 6.5 & 9.4 & & 10 & & & \\
\hline
\end{tabular}


Table 2 - Method error - paired $t$ test and Dahlberg's.

\begin{tabular}{|c|c|c|c|c|c|c|c|c|}
\hline \multirow{2}{*}{ Phases } & \multicolumn{2}{|c|}{ TPI - $1^{\text {st }}$ measurement } & \multicolumn{2}{|c|}{ TPI - $2^{\text {nd }}$ measurement } & \multirow{2}{*}{$t$} & \multirow{2}{*}{$\mathbf{p}$} & \multirow{2}{*}{ Dahlberg } & \multirow{2}{*}{ Sig } \\
\hline & Mean & SD & Mean & SD & & & & \\
\hline $\mathrm{T}_{1}$ & 6.51 & 0.98 & 6.99 & 1.28 & 1.53 & 0.185 & 0.544 & ns \\
\hline $\mathrm{T}_{2}$ & 1.34 & 1.06 & 1.42 & 1.08 & 0.97 & 0.373 & 0.126 & ns \\
\hline $\mathrm{T}_{3}$ & 1.57 & 0.84 & 1.51 & 0.8 & 0.97 & 0.373 & 0.094 & ns \\
\hline
\end{tabular}

Table 3 - TPI changes with FR-2 in the three assessed phases (ANOVA).

\begin{tabular}{ccccccc} 
Measure & Phase & Mean & SD & $\mathbf{n}$ & F value & $\mathbf{p}$ \\
\hline \multirow{3}{*}{ TPI } & $\mathrm{T}_{1}$ & 6.18 & 1.31 & 18 & & \\
& $\mathrm{~T}_{2}$ & 1.94 & 1.71 & 18 & 64.16 & $<0.001$ \\
& $\mathrm{~T}_{3}$ & 2.49 & 1.50 & 18 & & \\
\hline
\end{tabular}

a malocclusion and the need for treatment, besides the results of orthodontic treatments. ${ }^{13}$ Among them, there is the treatment priority index (TPI), recommended by Grainger, ${ }^{12}$ which assesses the occlusal characteristics.

According to several authors, ${ }^{2,3,24}$ TPI has been used as an efficient indicator of the presence and severity of malocclusion, as well as for assessing the effectiveness and need of orthodontic treatment. The present study chose to use the TPI occlusal index over the other indexes, for example, the PAR index. This was due to some peculiarities of the TPI, such as: 1) Measurement of posterior occlusal relation - in TPI the posterior occlusal relation is measured by the molar relationship, and in the PAR, it is measured by the intercuspation of the posterior teeth. Thus, a patient with a Class II, division 2 malocclusion, with complete molar relationship, could have a low score on the PAR, if the overjet was normal. However, this does not reflect the clinical difficulty of their treatment, as well as the importance of checking the molar relationship in the sample (initially presenting Class II); 2) In the PAR index, the lower anterior crowding does is not scored, unlike the TPI index, this is an important clinical data to be considered in terms of occlusal stability after treatment.

Considering that in recent decades scientific evidence has had great importance in dentistry, not only for determining results, but also for the
Table 4 - TPI changes with FR-2 in the three observed phases (Bonferroni's multiple comparisons test).

\begin{tabular}{ccccccc} 
Measure & \multicolumn{2}{c}{ Comparison } & Mean difference & Standard error & $\mathbf{p}$ \\
\hline \multirow{4}{*}{$\mathrm{TPI}$} & $\mathrm{T}_{2}$ & - & $\mathrm{T}_{1}$ & -4.24 & 0.43 & $<0.001$ \\
& $\mathrm{~T}_{3}$ & - & $\mathrm{T}_{1}$ & -3.70 & 0.42 & $<0.001$ \\
& $\mathrm{~T}_{3}$ & - & $\mathrm{T}_{2}$ & 0.55 & 0.37 & 0.478 \\
\hline
\end{tabular}

long-term stability, Perillo, Johnston and Ferro, ${ }^{23}$ in 1996, with this in mind, evidenced by cephalometric means the presence of longitudinal stability of effects promoted by FR-2 appliance. However, only Hime and Owen, ${ }^{14}$ in 1990, verified by means of study models the stability of the longitudinal effects of FR-2 in the lower dental arch, so that from 11 assessed patients, some used the fixed orthodontic appliance after treatment with FR-2 and others did not, which probably interfered on the occlusal outcomes. Furthermore, the posttreatment lasted 2-7 years after treatment, which of course, has resulted in equivocal results regarding the stability of the cases.

Therefore, the importance of further longitudinal studies is emphasized to evaluate the occlusal stability changes caused by the FR-2.

Thus, in this study, the treatment priority index was applied on models in order to demonstrate the degree of severity of Class II malocclusion at the beginning of treatment, correction of the same with the FR-2 appliance, in addition to the stability of these changes in the period of 6.66 years after retention. For that, the TPI was evaluated on plaster models at the beginning of treatment $\left(\mathrm{T}_{1}\right)$, after using the orthopedic FR-2 appliance, in a mean period of 18 months $\left(\mathrm{T}_{2}\right)$; and finally, 7.16 years after the end of the orthopedic treatment $\left(\mathrm{T}_{3}\right)$.

The results obtained in this study proved to be scientifically reliable, since no systematic or random error was detected (Table 2). 
The FR-2 appliance proved effective for the correction of Class II malocclusion, a fact verified by a statistically significant decrease of the scores of the initial phase to the end of treatment (Table 3). Initially, the mean score obtained was relatively high (6.18), specially because 11 patients had a complete Class II molar relationship and only 7 patients had end-on Class II; what also caused high scores was the overjet, with 16 patients presenting overjet between 5 and $9 \mathrm{~mm}$ and only two, with values greater than $9 \mathrm{~mm}$. Furthermore, as expected in a Class II, division 1 malocclusion, most patients had increased overbite, and more than $80 \%$ of the sample had overjet greater than $1 / 3$ of the crown of the lower incisors.

The correction of Class II malocclusion with FR-2 presented statistically significant values, as the final score obtained in stage $\mathrm{T}_{3}$, averaged 2.49 (Table 3 ), especially considering that no fixed orthodontic treatment was held after orthopedic treatment. By examining the TPI index obtained at the end of orthopedic treatment, it is verified that much of the achieved correction is due to improvement of the molar relationship, overjet and overbite. This fact was already expected, since the use of the orthopedic appliance really aims at the correction of malocclusion, especially in the sagittal direction and, secondarily, in the vertical direction. At this stage $\left(\mathrm{T}_{2}\right), 73 \%$ of patients had an overjet between 2 and 4 $\mathrm{mm}$ (normal rate) and only $27 \%$ showed a horizontal overlap greater than $5 \mathrm{~mm}$. These patients were probably those who at baseline had a horizontal overlap greater than $9 \mathrm{~mm}$, i.e., very severe. Also, 73\% of patients had normal vertical relationship at the end of orthopedic treatment, and only $27 \%$, an overbite between $1 / 3$ and $2 / 3$ of the crown of the lower incisor. This demonstrates the degree of occlusal correction only using FR-2.

Few changes were observed in the displacement/crowding using FR-2, although this appliance provides through its shields, a transverse increase in dental arches, which probably would promote an improvement in dental crowding. ${ }^{10,19}$ Initially, there were only two patients with two or three displaced teeth, reducing to one patient with two displaced teeth at the end of treatment. Probably this fact has occurred because of sample selection, because patients with moderate to severe crowding are not suitable for orthopedic treatment with FR-2 ${ }^{11}$ often needing extractions for alleviate crowding. Also, very smooth changes are probably not detectable by TPI index, which only measures dental displacements greater than $2 \mathrm{~mm}$ and dental rotations greater than $45^{\circ}$.

After 7.16 years after treatment with FR-2 appliance, only patients who had not undergone fixed orthodontic treatment were analyzed. A significant stability was observed, since there was statistically significant difference between initial and posttreatment score $\left(T_{1}\right.$ and $\left.T_{2}\right)$, and not between the final and posttreatment score $\left(\mathrm{T}_{2}\right.$ and $\mathrm{T}_{3}$ ) (Table 3 ). Thus, it can be asserted that 7.16 years after end of treatment for Class II malocclusion with the FR-2, there was occlusal stability of the changes caused by it, which corroborates with other studies that were conducted, however, in lateral cephalograms, ${ }^{23}$ or models, but for a shorter evaluation period. ${ }^{14}$

However, a small change in scores in the final phase of treatment and 7.16 years after removal of the FR-2 was found, from 1.94 to 2.49 , not statistically significant. It is observed that the changes occurred in the posttreatment were mild, with mean differences in the scores of only 0.55. This mild recurrence occurred mainly in the molar relationship and overjet, i.e., the main changes promoted by FR-2 during orthopedic treatment. This was expected, since the greater the change during treatment, more chances for relapse. ${ }^{16}$ In this sample, where the majority of patients had a complete Class II malocclusion some cases relapsed after 7.16 years, to a molar relationship of $1 / 4$ Class II. Perhaps this happened due to the absence of fixed orthodontic treatment, which would likely promote better dental intercuspation and consequently greater occlusal stability. ${ }^{22,23}$ Clinically, this mild recurrence was not even perceptible to patients, most of whom refused to perform the fixed orthodontic treatment.

\section{CONCLUSION}

This study showed that the FR-2 appliance proved to be effective for the occlusal correction of Class II malocclusion, acting mainly on the improvement of the overjet, overbite, and molar relationship. These occlusal effects were stable in the evaluated period of 7.16 years after orthopedic treatment. 


\section{REFERENCES}

1. Almeida G, Henriques JF, Ursi W. Comparative study of the Fränkel (FR-2) and Bionator appliances in the treatment of Class II malocclusion. Am J Orthod Dentofacial Orthop. 2002;121(5):458-66.

2. Barros SEC. Avaliação do grau de eficiência do tratamento da Classe II realizado sem extrações e com extrações de dois pré-molares superiores [dissertação]. Bauru (SP): Universidade de São Paulo; 2004.

3. Cançado RH. Estudo comparativo dos resultados oclusais e da eficiência dos protocolos de tratamento em uma e duas fases da má oclusão de Classe II, divisão 1 [tese]. Bauru (SP): Universidade de São Paulo; 2005.

4. Creekmore T, Radney L. Fränkel appliance therapy: orthopedic or orthodontic? Am J Orthod. 1983:83(2):89-108.

5. Cruz K, Henriques JFC, Dainesi EA, Janson GRP. Efeitos dos aparelhos funcionais na correção da má oclusão de Classe II. Rev Dental Press Ortod Ortop Facial. 2000;5(4):43-52.

6. DeVincenzo JP. Changes in mandibular length before, during and after successful orthopedic correction of Class II malocclusions, using a functional appliance. Am J Orthod Dentofacial Orthop. 1991;99(3):241-57.

7. Franco A. Avaliação dos discos articulares temporomandibulares empregando-se imagens por ressonância magnética em pacientes com oclusão normal e má oclusão de Classe II divisão 1a, tratados com regulador de função Fränkel RF-2 [dissertação]. São Bernardo do Campo (SP): Universidade Metodista de São Paulo; 2000.

8. Fränkel R. The theoretical concept underlying the treatment with functional correctors. Rep Congr Eur Orthod Soc. 1966;42:233-54.

9. Fränkel R, Fränkel C. Ortopedia orofacial: com o regulador de função. 1a ed. São Paulo: Santos; 1990.

10. Ghafari J, Shofer FS, Jacobsson-Hunt U, Markowitz DL, Laster LL. Headgear versus function regulator in the early treatment of Class, division 1 malocclusion: randomized clinical trial. Am J Orthod Dentofacial Orthop. 1998;113(1):51-61.

11. Graber TM, Neumann B. Aparelhos ortodônticos removíveis. 2ª ed. São Paulo: Panamericana; 1987.

12. Grainger RM. Orthodontic treatment priority index. Vital Health Stat 1967;25(2):1-49
13. Hill P. The prevalence and severity malocclusion and the need of orthodontic treatment in 9, 12 and 15 year-old. Glasgow schoolchildren. Br J Orthod. 1992;19(2):87-96.

14. Hime DL, Owen AH. The stability of the arch-expansion effects of Fränkel appliance therapy. Am J Orthod Dentofacial Orthop. 1990;98(5):437-45.

15. Houston WJB. The analysis of error in orthodontic measurements. Am J Orthod. 1983;83(5):382-90

16. Janson G, Caffer DC, Henriques JF, de Freitas MR, Neves LS. Stabilility of Class II, division 1 treatment with the headgear-activator combination followed by the edgewise appliance. Angle Orthod. 2004;74(5):594-604.

17. Janson G, Toruño JLA, Martins DR, Henriques JFC, Freitas MR. Class II treatment effects of the Fränkel appliance. Eur J Orthod. 2003;25(3):301-9.

18. Kerr W, Ten Have T, McNamara JA Jr. A comparison of skeletal and dental changes produced by function regulators (FR-2 and FR-3). Eur Orthod Soc Trans. 1989;11(3):235-42.

19. McDougall PD, McNamara JA Jr, Dierkes JM. Arch width development in Class II patients treated with the Fränkel appliance. Am J Orthod. 1982;82(1):10-22.

20. McNamara JA Jr, Bookstein F, Shaughnessy T. Skeletal and dental changes following functional regulator therapy on Class II patients. Am J Orthod. 1985;88(2):91-110.

21. McNamara JA Jr. Components of Class II malocclusion in children 8-10 years of age. Angle Orthod. 1981;51(3):177-202.

22. Pancherz $\mathrm{H}$. The Herbst appliance: its biologic effects and clinical uses. Am J Orthod. 1985;87(1):1-20.

23. Perillo $L$, Johnston $L J$ r, Ferro $A$. A permanence of skeletal changes after function regulator (FR-2) treatment of patients with retrusive Class II malocclusions. Am J Orthod Dentofacial Orthop. 1996;109(2):132-9.

24. Popovick F, Thompson GW. A longitudinal comparison of the orthodontic treatment priority index and the subjective appraisal of the orthodontist. J Public Health Dent. 1971;31(1):2-8.

25. Rushforth DJ, Gordon H, Aird C. Skeletal and dental changes following the use of the Fränkel functional regulator. Br J Orthod. 1999;26(2):127-34 